821.163.41.09-14

821.163.41.09-95 Поповић Б. https://doi.org/10.18485/kij.2019.66.2.2

ПРЕДРАГ Ж. ПЕТРОВИЋ*

Универзитет у Београду

Филолошки факултет
Оригинални научни рад

Примљен: 31. 10. 2019.

Прихваћен: 02. 12. 2019.

\title{
ПУСТИТЕ МЕ КАКО ЈА ХОЋУ: О „ТРЕЋЕМ ДОБУ” У АНТОЛОГИЈИ БОГДАНА ПОПОВИЋА
}

\begin{abstract}
У раду се разматра избор песника и песама који је Богдан Поповић начинио у „Трећем добу" Антологије новије српске лирике. У овој целини нашли су се најмлађи песници, рођени на измаку седамдесетих и током осамдесетих година деветнаестог века. Да би одредио поетику тога доба, које отварају песме Милана Ћурчина „Пустите ме како ја хоћу!” и „На странпутици”, Поповић користи појам неоварварство, што је сасвим блиско термину фовизам који је током прве деценије двадесетога века добио легитимитет у сликарству. У завршној целини Антологије новије српске лирике Богдан Поповић се показао као аутор отворен за песничке гласове младих стваралаца.
\end{abstract}

Кључне речи: антологија, поезија, лирика, Богдан Поповић, естетика.

При крају предговора Антологији новије српске лирике (1911) Богдан Поповић пожелео је својој књизи „што више читалаца и што више пријатеља” (Поповић 1911: XIX). Имао је ту срећу да му се жеља испуни - још за Поповићевог живота објављено је осам, а до данас двадест и четири издања ове антологије, што је чини једном од најчитанијих књига поезије код нас. О томе колики је био значај и утицај прве модерне српске антологије најбоље сведочи један од њених најпосвећенијих читалаца, велики српски песник Иван В. Лалић. Истичући њену сталну присутност у различитим периодима наше књижевности, било да су Поповићева естетска мерила и избор прихватани или, пак, оспоравани, Лалић признаје да је управо из тог „цветника” највише научио о песничком умећу и стихотворачкој вештини:

Да нисам, као дечак, страсно читао Антологију Богдана Поповића, не бих зацело могао касније да препевам Хелдерлина. (...) Да се разумемо: моја песничка основна школа била је Антологија новије српске лирике. То значи и да сам пропевао у везаном стиху (махом

"pedja611@yahoo.com 
у једанаестерцима и дванаестерцима). А када сам написао своју прву песму у такозваном слободном стиху, чију сам музику наслутио у мелодији стиха Војислава Илића, осећао сам се као да сам управо измислио тај слободни стих. (Лалић 1997: 276-279)

Лалићеви искази важни су не само као пример значаја који је Поповићева антологија имала за формирање овога песника него и због другог разлога. Наиме, могло би се поставити питање зашто је Лалић „наслућивао” слободни стих у хексаметрима Војислава Илића када у избору песама што га је сачинио Богдан Поповић већ постоји аутор који је недвосмислено, без икаквог наслућивања, писао у форми слободног стиха? То је Милан Ћурчин чије песме „Пустите ме како ја хоћу!” и „На странпутици” отварају трећу композициону целину Антологије. Не само по иницијалној позицији, него и по броју песама којима је заступљен, а има их осам, Ћурчин је водећи песник „Трећег доба”. Данас је он готово заборављен књижевник и то што га Лалић не помиње није нимало случајно. Али један други песник својеверно није хтео да „прескочи” Ћурчина. У аутопоетичкој песми „Пролог”, којом отпочиње Лирика Итаке (1919) Милоша Црњанског, налазе се и чувени стихови: „Нит марим за славу Поетика. / Нећу да прескочим Крлежу, ни Ћурчина”. Као песника који је на почетку прошлога века не само писао слободним стихом, него се и у програмским есејима залагао за стих који није вођен метричким диктатом, већ мелодијом и емоцијом, Милана Ћурчина је Црњански сматрао претходником кога вреди поменути. Али већ у време када су написни наведени стихови, Ћурчинова слава којом га је овенчао Богдан Поповић, већ је почела да бледи. И не само његова. Скоро сви песници „Трећег доба” Антологије новије српске лирике постепно су падали у заборав. Једини аутори из тог избора чије су песме сачувале сигуран антологијски статус у наступајућим деценијама су Сима Пандуровић и Вељко Петровић. Ипак, Петровић у годинама након Великог рата није више писао поезију, постајући све значајнији приповедач. Што се Пандуровића тиче, два његова остварења, „Светковина” и „Ми, по милости Божјој, деца овог столећа", Поповић је изоставио из свог избора када је 1936. године приређивао седмо издање Антологије. Тако је „Треће доба” остало „на странпутици”модерне српске поезије, да употребимо наслов Ћурчинове песме.

Више од једног века након првог издања, у Загребу 1911. године, јасно је да читаоци а посебно критичари, нису подједнако заволели све ауторе, песме и раздобља Поповићевог „цветника”. И у новом веку се о овој књизи с правом говори као о „Дучићевој антологији” (Ракитић 2012: 20) односно као избору начињеном првенствено да би се естетски канонизовала парнасовска линија српске поезије на измаку деветнаестог и почетком двадесетога столећа, којој су поред Јована Дучића припадали још Војислав Илић, Милан Ракић и Алекса Шантић. Њихове су песме убедљиво најбројније. То је оно „Друго доба” Антологије које са становишта књижевноисторијске периодизације данас одређујемо као модерну, а за које се одавно усталио сликовити назив „мали златни век српске поезије”, и то првенствено захваљујући Поповићевом одабиру који је то ,златно доба” први естетски артикулисао и уобличио. 
Иако Богдан Поповић не користи периодизацијска одређења, јер је првенствено фокусиран на песме а мање на поетички контекст њиховог настанка, он је ипак, поред естетских, морао да разреши и нека књижевноисторијска питања, о чему пише у предговору. Новија српска лирика за Поповића обухвата раздобље од Бранка Радичевића, а то значи и од Вукове језичке реформе, па до краја прве деценије двадесетога века, јер то је ,једна заокругљена органска целина (...) која показује изванредно правилан, управо типичан развој једне оригиналне лирске цвасти" (Поповић 1911:VII). У овом исказу препознају се обриси еволуционистичке концепције развоја књижевности која је, под утицајем Дарвинових идеја, крајем деветнаестог века била присутна у расправама о естетици и историји уметности (В. о томе: Гилберт, Кун 2004: 388-389). Таква концепција важна је за разумевање зашто је Поповић одлучио да свој избор започне песмама Бранка Радичевића а оконча га стиховима Милана Ћурчина и Велимира Рајића. Због ослањања на народну поезију Радичевићеве песме су, према нашем антологичару, својим мотивима, стихом и мелодијом „просте”, „примитивне”, „полу уметничке", што је управо карактеристично за сваки почетак лирске књижевности. Наравно, данас су овакве оцене Радичевићеве поезије сасвим неприхватљиве, јер је његов тематски и метрички распон знатно богатији него што га Поповићев избор представља песмама „Рибарчета сан”, „Враголије” или одломцима из поеме „Ђачки растанак”. Али, да би се према еволуционистичком начелу образовала органска целина, Поповићу је потребна управо таква, „наивна”, из народне поезије произашла лирика која ће потом у стиховима Змаја, Ђуре Јакшића и Лазе Костића постајати сложенија, прожета дубљим осећањима и јачим темпераментом, што се види у песмама „Првог доба” Антологије, који обухвата романтичарско песништво. Врхунац уметничке уобличености, односно виртуозности стиха, култивисаности емоције и мисане истанчаности, новија српска лирика, према Поповићу, добија у поезији Војислава Илића, Милана Ракића и Јована Дучића који бројем песама предњаче не само у „Другом добу” него и у целини избора. Заправо, могло би се рећи да је своја три чувена естетска критеријума на основу којих је бирао песме - емоциналност, јасност и лепоту, Поповића извео управо на основу Дучићевих и Ракићевих песама. Као да су оне биле онај поетски и естетски еталон на основу којега је вредновао стихове других аутора. Коначно, долазимо и до „Трећег доба” у којем има најмање песама (тридест и седам), а највише песника (дванаест). Поређења ради, у „Првом добу” има седам песника и четрдест осам песама, а у „Другом добу” осам песника и чак осамдесет две песме, од којих су тридест и две Дучићеве. Број песама није мерило које у антологијама треба прецењивати, али ни потцењивати, поготову не у овој где je аутор, види се то и из предговора, сваки стих пажљиво процењивао и строго водио рачуна о распореду песама, њиховим односима, пропорцијама и складу.

Избор који је Поповић начинио у прве две целине сасвим је очекиван, имамо ли у виду његове претходно објављене огледе и критике, махом на страницама утицајног Српског књижевног гласника. Реч је о текстовима као што су „О васпитању укуса”, „Шта је велики песник?”, „О песмама А. Шантића” 
и „Гордана Лазе Костића”. Маргинализована позиција Лазе Костића, који је у Антологији заступљен једном, али изузетном, песмом, „Спомен на Рувараца”, и са два одломка из драме Максим Црнојевић, произилази из негативних оцена које је Богдан Поповић, поводом драме Гордана, изнео о Костићевом песничком умећу - недостатак јасности, стилска аљкавост, изостанак хармоније делова и целине. У том огледу Поповић се, између осталог, позива на ставове француског парнасовца Силија Придома као мерила песничке вредности. Ако знамо да је парнасовско песништво настало као директна реакција и супротстављање романтизму, онда је јасно да Поповићеве естетска и критичка начела нису била ни најмање благонаклона према стиховима Лазе Костића. И не само према њему. У студији „Шта је велики песник?” Поповић одговара на ово питање, тумачећи и вреднујући песме Јована Јовановића Змаја. Одговор до којег долази је да Змај, који је водећи аутор „Првог доба” Антологије, није велики песник, што недвосмислено упућује на став који је арбитар укуса из доба модерне имао према романтичарским књижевницима. С друге стране, афирмација Дучићевих, Ракићевих или Шантићевих стихова такође је очекивана и произашла из Поповићевих до тада објављених критика и расправа.

Међутим, избор песама у „Трећем добу” прилично је изненађујући. И сам Поповић био је, изгледа, свестан да би читоци могли имати такву реакцију на овај део књиге, па зато у предговору жели додатно да оправда свој одабир стихова „извесних песника":

Ако је у ову Антологију унео песме извесних песника (које ће читалац наћи на свом месту у „Трећем добу”), он то није учинио по укусу данашње незреле и разметљиве моде у земљама средње Европе, зарад онога што је у песништву тих песника 'сензационално', 'сексуално', 'криминално', 'патолошко' (...), но просто стога што у песмама тих песника има правог песничког. (Поповић 1911: XIII)

У овој целини нашле су се песме које бисмо данас могли сврстати у поетику дезинтеграције модерне. Њихови аутори су, у том моменту, најмлађи песници, рођени на измаку седамдесетих и током осамдесетих година деветнаестог века. Куриозитет је да неки од њих у време објављивања ове антологије нису чак ни имали објављене збирке, попут Душана Срезојевића, Вељка Петровића или Мирка Королије. И по томе је Поповићева књига јединствена. Наиме, ниједан каснији антологичар српске поезије неће у свој избор унети толико младих аутор као што је то учинио Богдан Поповић. То поготово нису учинили Зоран Мишић у Антологији српске поезије (1956) и Миодраг Павловић у Антологији српског песништва (1964), које су уз Поповићеву, наше најутицајније песничке књиге ове врсте. Зато се с правом може рећи да „Треће доба” доводи у питање оцену о Поповићу као конзервативном критичару. Он у годинама пред Први светски рат има слуха за иновације у поезији, али, ипак, само до извесне мере. Индикативно је да у предговору он највише пажње посвећује управо завршном добу, употребљавајући низ одређења којима настоји да што детаљније и прецизније опише поетичка струјања у српској лирици новога века: 
Најзад, поколебаност, узнемиреност, иронија, сумња, песмимизам (уз афирмацију живота), фамилиарност, нешто анархије, сувише отворене личне исповести, у стилу неправилном и мутном, често сплетеном, у облику разглабављеном: „сецесија” и декадентизам, али са клицама обнове у себи. То је великим делом, долазак примитива у културну средину и међу високо културне тековина - неоварварство. (Поповић 1911: VII, подвлачење је ауторово)

Поповић је врло прецизно и савим тачно описао не само оне књижевне тенденције које ће обележити српску поезију на измаку модерне, него и оне које ће бити доминантне у годинама након Великог рата. Сва ова одређења сасвим пристају уз ону поетику и књижевни период који данас одређујемо као авангарду. Поповић свакако није би њен апологета, напротив. Почетком двадесетих година прошлога века у студијама „Каква је уметничка вредност црначке пластике” и „Стеван Маларме, Симболизам и други изми” оштро је осудио модернистичке струје у европској уметности, поставши један од главних опонената авангрдним уметницима. Међутим, у тренутку када саставља Антологију он је те нове тенденције спреман да прихвати и разуме, али само као привремено опадање високо успостављеног поетичког квалитета, декаденцију која у себи носи клицу обнове. Дакле, управо у складу са начелима еволуционистичке естетике „Треће доба” било је потребно да би се стваралачки круг српске лирике смисано и складно затворио. Као што су на почетку те песничке еволуције биле „примитивне”, „полу уметничке” песме Бранка Радичевића, тако се на крају тог развојног лука поново јављају сличне одлике означавајући смирај једног и почетак новог развојног периода. Индикативан је термин који Поповић користи да би именовао поетику тог завршног доба - неоварварство. То је сасвим блиско термину фовизам, који је током прве деценије двадесетога века добио легитимитет у сликарству. Од француске речи fauves, што значи дивље звери, изведено је 1905. године име сликарског правца који је у тадашњу европску уметност донео нову визију стварности, некултивисану и неукроћену дотадашњим ликовним конвенцијама и техникама. „Не може се живети у сувише уредном домаћинству”, пише у то време Анри Матис, најзначајнији представник фовизма, „Опет се обнавља дивљина да би се створила једноставнија средства која не гуше дух." (Нав. према: Трифуновић 1994: 43) Могуће да је Поповић, добро обавештен о модерној европској уметности, одредницу неоварварство употребио имајући у виду француски фовизам. Међутим, он је тим новим, „неоварварским" струјањима у српској лирици ипак нашао место у свом уредном и хармонично склопљеном антологичарском „домаћинству”. Генерацију песника чији стихови су, често програмски самосвесно као у случају Ћурчина и Пандуровића, у знаку ироније, сумње и анархије, Поповић није желео да види као потпуну негацију или супротност дотадашњим песничким токовима, него као природни развој једне ,лирске цвасти“ која је дошла у фазу опадања пред нови циклус обнове. Не треба занемарити ни музичко начело распоређивања и компоновања књиге, што аутор истиче у предговору. У том смислу „Треће доба” је онај завршни акорд Антологије у којој су песме слагане по „начелима склада и контраста” 
(Поповић 1911: XVII). Завршна песничка целина је зато и својеврсни смисаони и музички контрпункт оној метричкој виртуозности „Другог доба”.

Који су, дакле, ти песници „неоварвари” у Поповићевој антологији? На првом месту то је, како смо већ истакли, Милан Ћурчин, аутор који се не само афирмисао него готово и целину свог опуса објавио на страницама Српског књижевног гласника од 1902. до 1914. године. У истом часопису Ћурчин је публиковао и низ запажених студија о стиху („Версификација Милана Ракића”, „Јампски стих у српском песништву”), потом књижевних критика, огледа из германистике, те, коначно, и свој песнички програм „О мојим песмама” (1903). Програмског су карактера и две Ћурчинове песме, обе први пут објављене 1902. године: „На странпутици”, која је до седмог издања Антологије (1936) била на почетку „Трећег доба”, и „Пустите ме како ја хоћу!”, која ће од тада преузети ту иницијалну позицију. Поповић је очигледно одлучио да промени првобитни редослед, желећи да истакне моменат индивидуалности, па и дрскости, који је присутан у песмама „Трећег доба”. Међутим, индикативно је да баш у песми „Пустите ме како ја хоћу!” лирски субјекат отворено устаје против једног од Поповићевих естетских начела: „Зар све баш мора бити јасно и чисто, / И свуда про́писан број!?” Заправо, чини се да завршни део Поповићевог избора из новије српске лирике представља својеврсну антологију у антологији, која има своје особене критеријуме који се нешто разликују од оних прокламованих у предговору. То је, усталом, приметио и Јован Скерлић, када у својој оцени истиче да је „у најмлађој поезији нашој указана првелика и незаслужена пажња извесним конфузионистима, снобовима и мистификаторима”, наводећи као пример Душана Срезојевића и његов „Унутрашњи дијалог”. Песме овога доба имају другачији квалитет емоција и нису ни јасне ни лепе на онај начин као што су то стихови Војислава Илића или Јована Дучића. Поповићу као да је овде више било стало да окупи и афирмише оне ауторе, односно песничка остварења, која својом формалном и смисаоном иновативношћу доносе дух немира и кризе, али и отварају врата новом типу односа лирског субјекта према стварности и поезији. То је очигледно у Ћурчиновим песмама које не само да су испеване у слободном стиху, него повремено пародирају затечену традицију, као у песми „На странпутици”, која се иронично односи према романтичарским, али, изгледа, и према симболистичким општим местим. И према једној и према другој поетици Поповић је био уздржан. Милан Ћурчин је зато онај „весник српског модернизма" (Петров 1996: 5) који је био по Повићевом укусу, више него што су то били Станислав Винавер и Димитрије Митриновић који у Антологију нису ни ушли. Ћурчин је био онај крајњи песнички домет неоварварства који је Поповић био спреман да прихвати.

Још један аутор чије песме дају печат „Трећем добу” је Сима Пандуровић, заступљен са две, и до данас врло цењене, песме из збирке Посмртне почасти (1908). То су програмска „Ми, по милости Божјој, деца овог столећа” и „Светковина”. Јован Скерлић је у једној од својих најпознатијих критика, „Једна књижевна зараза", био врло оштар у оцени Пандуровићеве збирке. Иако му не 
одриче таленат, Скерлић га назива песником безумља и „болесног песмимизма” (Скерлић 1964: 59). Ти ставови нису поколебали Поповића у намери да уврсти овог песника у Антологију. Занимљиво је да ће Пандуровић у предговору другом издању Посмртних почасти (1922) посебно нагласти да су управо његове песме биле предмет неслагања и опречних судова двојице водећих судија књижевног укуса у периоду пре Великог рата. Песма „Светковина”, која слави лудило као могућност избављења из окова грађанског друштва, остаће незаобилазна у готово свим каснијим антологијама српске поезије. Међутим, у седмом издању Поповић је, без икаквог образложења, изоставио обе Пандудровићеве песме. Дакле, опет је у „Трећем добу” имао неке посебне критеријуме и баш у том делу књиге вршио највеће измене. Разлози за брисање Симе Пандуровића највероватније су били сасвим лични, без икакве примесе естетских начела. Наиме, 1931. године Пандуровић је објавио дужу студију о Богдану Поповићу у којој је, уз похвалне, изнео низ заједљивих оцена о животу и делу великог проучаваоца књижевности. Поповић му то није опростио. Уосталом, изгледа да му то није било први пут да статус једног песника одреди на основу личног анимозитета. ${ }^{1}$ Можда баш због таквих, осетљивих и дискутабилних одлука, Поповић у предговору истиче да поред објективних естетских мерила у књижевним оценама увек и неминовно постоји уплив субјективног става. „Укус је резултат личних искустава; јасно је да се лична искуства свих људи не могу потпуно поклапати." (Поповић 1911: XVI)

Готово ниједан аутор из „Трећег доба” није наставио песничку каријеру. У годинама након Првог светског рата Сима Пандуровић спорадично ће писати поезију, а знатно више ће се посветити преводилаштву, критици и публицистици. Иако су Посмртне почасти многим авангардним песницима биле једна од најдражих књига, Пандуровић ће почетком двадесетих година бити један од њихових главних опонената. Од писања поезије ће након Великог рата одустати и Вељко Петровић, кога наша књижевност данас памти првенствено као великог и изразитог приповедача. У време модерне био је цењен као обновитељ наше родољубиве поезије, али Поповић у Антологију укључује само једну његову песму такве тематике („Верујте право”) док су остале три у знаку љубавних и егзистенцијалних мотива. У „Трећем добу” нашла се и једина песникиња у Поповићевој књизи, Даница Марковић. Њена интимна, љубавна лирика прожета је наглашеним доживљајима природе, што је чини претходницом Десанке Максимовић. У новије време историчари књижевности значајну пажњу посвећују Светиславу Стефановићу који је са пет песама заступљен у завршници Антологије. Међутим, та пажња је у потпуности усмерена на Стефановића као аутора који је својим критикама и полемикама, а не толико поезијом, био

${ }^{1}$ У књизи Итака и коментари (1959) Милош Црњански сећа се како је питао Богдана Поповића зашто је имао тако негативно мишљење о Костићевом књижевном раду. Овај му је као одговор испричао о непријатном сусрету са Костићем у купеу воза. Костић том прилком није удостојио ни поздрава браћу Поповиће. Богдан је зато одлучио да првом следећем приликом када буде писао о Костићу, „том неуљудном човеку”, „притисне перо” (Црњански 2008: 209). 
један од „родоначелника модернизма” (Тешић 1991: 228). Његова дескриптивна и љубавна поезија садржи управо оне „клице обнове” које Поповић помиње у предговору, рецимо у стиховима песме „Пролеће”: „Ја осећам како у мени ради / Живота светског вечно подмлађење". Ипак, ова, као и остале Стефановићеве песме из тог времена, делује данас прилично конвенционално и без изразитије иновативности. Али, зато његови критички текстови, какав је „Част и слобода творцима!” (1911) написан у одбрану Дисове поезије, својим авангардним ставовима иду испред тог времена. Светислав Стефановић био је један од тројице песника заступљених у Антологији који је одмах по њеном објављивању, јавно изрекао мишљење о Поповићевим мерилима и избору аутора и песника. Док је Сима Пандуровић тврдио да је она „савесно израђена, уметнички склопљена и укусом проткана” (Пандуровић 1979: 287), а Милан Ћурчин у њој видео књигу „најбољег од свега што су наши песници до сада дали” (Ћурчин 1911: 167), Стефановић је био другачијег мишљења. На позив Трајка Ћирића, што је био псеудоним Станислава Винавера, Стефановић је у београдском Пијемонту оценио да су због изостављања не само неких песника, него и читаве естетске категорије ружног, Поповићева мерила површна и недовољно модерна. Књига коју је саставио „испала је у лепоти својој некако хладна, празна, скоро бих рекао без душе" (Стефановић 1911: 2). Посебно је поменуо тројицу изостављених песника: Винавера, Димитрија Митриновића и Владислава Петковића Диса. И данас би се могло рећи да је један од одређујућих момената „Трећег доба” управо одсуство Дисових песама. Поред маргинализовања Лазе Костића, то је други велики „случај” Антологије. Збирка Утопљене душе, објављена је исте године када и књига Богдана Поповића, изазвала је опречене реакције међу ондашњим критичарима, али најпознатији и најубојити текст о њој написао је, наравно, Јован Скерлић - „Лажни модернизам у српској поезији”. Да ли је и Поповић делио изразито негативно мишљење о Дисовим песмама? У огледу „Јован Скерлић као књижевни критичар" (1914) Поповић ће поменути како је у једном разговору покушао да свом млађем колеги и пријатељу укаже да, и поред тога што је његова оцена Утопљених душа „у основи тачна” она, ипак, није уочила извесне финесе и квалитете у појединим песмама:

Ја сам му, у разговору, поменуо да тај песник - кажем „тај песник” да бих избегао онај немогући, неопростиви псеудоним - да тај песник има лепих стихова, меких, и као угашено светлих, боје старога сребра. (Поповић 1959: 364)

Дакле, Поповић је сматрао да Дис има изузетних стихова, али можда не и целих лепих песама. Могуће да му је, ипак, највише замерао што је поезијом, а и „неопростивим” псеудонимом, и сувише доводио у питање неке књижевне и грађанске конвенције. Али за разлику од Милана Ћурчина, који такође устаје против тих конвенција, Дис није припадао оном академском кругу који је сарађивао у Српском књижевном гласнику и који је био под својеврсним Поповићевим патронатом. Ипак, у „Трећем добу” било је места за песника који је својим лирским сензибилитетом и сликом света био близак Дису. То је скоро 
заборављени Велимир Рајић, заступљен са чак седам песама, од којих је само једна, „На дан њеног венчања”, до данас позната широј публици и то под именом свог првог, за Рајићеву поетску визију живота и љубави карактеристичним, стихом: „И срушише се лепи снови моји”. Трагично поимање егзистенције, ирационалне слутње и, коначно, доживљај света као тамнице, у песми „Завет”, одлике су Рајићеве поезије. У новије време Новица Петковић је скренуо пажњу на то да је у једној од најпознатијих Дисових песма, „Тамници”, приметан утицај Рајићеве песме „Вјерују”. Обе су објављене у часопису Ново време, Рајићева 1909 , а Дисова годину дана касније. Поред низа блиских мотива и симбола оне деле и један сличан стих: „Код Рајића је рођење дошло 'Без мог знања и без моје воље', а код Диса је пад у овај живот дошао 'Са нимало знања и без моје воље'." (Петковић 2004: 84)

Желећи да представи најмлађу песничку генерацију која се афирмисала током прве деценије даведесетог века, Поповић је прилично ризиковао и, показаће се, прилично погрешио. Док је у првој и другој целини Антологије готово без грешке оценио новију српску лирику - једини изузетак је, наравно, потцењена вредност песама Лазе Костића - у трећем делу одабарао је углавном песнике који нити су издржали суд времена, какав је Ћурчин, нити су били носиоци далекосежних иновативних тенденција у нашој поезији, као што је то изостављени Дис. То је очигледно ако Поповићево „Треће доба” упоредимо са избором који су начинила друга два велика антологичара, Зоран Мишић и Миодраг Павловић. У Мишићевој Антологији српске поезије један од водећих песника је управо, код Поповића изостављени, Дис. Високу позицију сачуваће и Вељко Петровић, али савим другачијим избором песма, космичке и визионарске инспирације. Са по једном песмом ту су и Сима Пандуровић, Стеван Луковић и Душан Срезојовић. Слично је и у Павловићевој Антологији српског песништва, осим што овај аутор уместо Луковићу предност даје Велимиру Рајићу. Коначно, у обе антологије присутан је и Милутин Бојић који у време док је Поповић састављао свој избор, још није објављивао. Ипак, јасно је да и Мишић и Павловић у својим књигама обухватају веће временске распоне, па је у таквој конкуренцији од „Трећег доба” и морало остати мање песника. Међутим, ствари су нешто другачије у Антологији српске лирике 1900-1914 (2001) Леона Којена која је управо фокусирана на период модерне у нашој поезији. Упоредимо ли „Треће доба” са Којеновим избором видимо да потоњи антологичар највише места даје песмама Диса, Симе Пандуровића, Вељка Петровића и Милутина Бојића. Од круга Поповићевих аутора ту су, са скромним бројем остварења, остали Светислав Стефановић, Стеван Луковић, Душан Срезојевић, Даница Марковић и Душан Симић. Видно је да нема ни Милана Ћурчина ни Велимира Рајића. Иако се са Којеновим избором не морамо у потуности сагласити, јер и он отвара низ дилема о вредновању српске поезије, поготово оне у слободном стиху, ова новија антологија потврђује да је Поповићев избор и даље незаобилазан и одређујући за процену српске поезије с почетка прошлога века. У сваком случају, ако су неки од песника из Поповићеве 
књиге данас скоро заборављени, „то није разлог да их дефинитивно отписујемо” (Лалић 1997: 248). Коначно, Богдан Поповић се у завршном акорду Антологије новије српске лирике показао као аутор отворен за песничке гласове младих стваралаца, што је међу критичарима из академских и факултетских кругова и данас ретка појава.

\section{ИЗВОРИ}

Поповић 1911: В. Popović, Antologija novije srpske lirike, Zagreb: Matica hrvatska.

Поповић 1959: Б. Поповић, Огледи и чланщи из књижевности, Београд: Просвета.

\section{ЛИТЕРАТУРА}

Гилберт, Кун 2004: K. E. Gilbert, H. Kun, Istorija estetike, prev. D. Puhalo, Beograd: Dereta.

Лалић 1997: И. В. Лалић, „Достигнућа првог антологичара”, O поезији, Београд: Завод за уџбенике и наставна средства.

Пандуровић 1979: С. Пандуровић, „Богдан Поповић: Антологија новије српске лирике", у: Писии као критичари пре Првог светског рата, Нови Сад: Матица српска.

Петковић 1994: Н. Петковић, „Дисов језик, слике и музика стиха”, Огледи о српским песницима, Београд: Друштво за српски језик.

Петров 1996: А. Петров, „Ћурчин - Гласников весник српског модернизма", Српски модернизам, Београд: Просвета.

Ракитић 2012: С. Ракитић, „Антологија песме, а не песника”, Политика, 10. фебруар 2012, стр. 29.

Скерлић 1964: Ј. Скерлић, „Антологија новије српске лирике Богдана Поповића", Писии и књиге, књ. 5, Београд: Просвета.

Стефановић 1911: С. Стефановић, „Одговар на анкету г. Трајка Ћирича”, Пијемнонт, 18. септембар 1912, стр. 1-3.

Тешић 1991: G. Tešić, Srpska avangarda i polemički kontekst, Novi Sad: Svetovi.

Трифуновић 1994: Л. Трифуновић, Сликарски правичи у 20. веку, Београд: Просвета.

Ћурчин 1911: М. Ћурчин, „Богдан Поповић (Фрагменти)”, Српско-хрватски алманах, Београд, стр. 161-167.

Црњански 2008: М. Црњански, Лирика Итаке и коментари, Београд: Октоих. 
Predrag Ž. Petrović

\title{
THE THIRD PART OF BOGDAN POPOVIĆ'S ANTOLOGIJA NOVIJE SRPSKE LIRIKE
}

\begin{abstract}
Summary
The paper discusses the selection of poets and poems made by Bogdan Popović in „The Third Age" of Antologija novije srpske lirike (1911). The youngest poets, born at the end of the seventies and during the eighties of the nineteenth century, were found in this part of anthology. In the final part of the anthology Bogdan Popović proved to be an author open to the poetic voices of young creators. Wanting to present the youngest poetry generation that affirmed itself during the first decade of the nineteenth century, Popović took the most risk and, as it turns out, was most wrong.
\end{abstract}

Key words: anthology, poetry, modernism, Bogdan Popović, aesthetics. 